\title{
Volatile organic emissions from the distillation and pyrolysis of vegetation
}

\author{
J. P. Greenberg, H. Friedli, A. B. Guenther, D. Hanson, P. Harley, and T. Karl \\ National Center for Atmospheric Research, Boulder, Colorado, 80307-3000, USA \\ Received: 4 August 2005 - Published in Atmos. Chem. Phys. Discuss.: 22 September 2005 \\ Revised: 7 December 2005 - Accepted: 9 December 2005 - Published: 13 January 2006
}

\begin{abstract}
Leaf and woody plant tissue (Pinus ponderosa, Eucalyptus saligna, Quercus gambelli, Saccharum officinarum and Oriza sativa) were heated from 30 to $300^{\circ} \mathrm{C}$ and volatile organic compound (VOC) emissions were identified and quantified. Major VOC emissions were mostly oxygenated and included acetic acid, furylaldehyde, acetol, pyrazine, terpenes, 2,3-butadione, phenol and methanol, as well as smaller emissions of furan, acetone, acetaldehyde, acetonitrile and benzaldehyde. Total VOC emissions from distillation and pyrolysis were on the order of $10 \mathrm{gC} / \mathrm{kgC}$ dry weight of vegetation, as much as $33 \%$ and $44 \%$ of $\mathrm{CO}_{2}$ emissions ( $\mathrm{gC}(\mathrm{VOC}) / \mathrm{gC}\left(\mathrm{CO}_{2}\right)$ ) measured during the same experiments, in air and nitrogen atmospheres, respectively.

The emissions are similar in identity and quantity to those from smoldering combustion of woody tissue and of different character than those evolved during flaming combustion. VOC emissions from the distillation of pools and endothermic pyrolysis under low turbulence conditions may produce flammable concentrations near leaves and may facilitate the propagation of wildfires. VOC emissions from charcoal production are also related to distillation and pyrolysis; the emissions of the highly reactive VOCs from production are as large as the carbon monoxide emissions.
\end{abstract}

\section{Introduction}

Combustion of vegetation occurs in several consecutive stages: distillation, endothermic pyrolysis, exothermic pyrolysis, ignition, flaming combustion and smoldering combustion. Gaseous organic and inorganic emissions, as well as readily condensable compounds (tars), are produced during these stages. However, the composition and rates of emission vary significantly among the different combustion stages.
Numerous reports have identified and quantified volatile organic compounds (VOC) emissions from wildfire processes (Andreae and Merlet, 2001; Christian et al., 2003). The regional (e.g. Wotawa and Trainer, 2000) and global (Crutzen and Andreae, 1990) influence of emissions on atmospheric chemistry and radiation is very large, because many of the gaseous emissions are very reactive and primary and secondary aerosols from fires scatter or absorb solar radiation. Emission ratios (expressed relative to $\mathrm{CO}_{2}$ or $\mathrm{CO}$ emissions) or emission factors (g emission/ $\mathrm{kg}$ fuel burned) for VOCs have been derived from laboratory experiments, measurements of fires at ground-level, or by aircraft in smoke plumes. Samples are often collected into canisters and analyzed at a remote laboratory by GC-FID or GC-MS (e.g., Greenberg et al., 1984; Friedli et al., 2001) or are analyzed by on-line techniques (Lobert et al., 1991; Yokelson et al., 1996; Bertschi et al., 2003a, b). Smoke plume studies typically do not characterize VOC emissions from different stages of combustion, since most plumes include a combination of all stages.

The work presented is focused on those emissions that occur during the pre-flaming stage of fires. These emissions arise during the initial heating of vegetation up to $300^{\circ} \mathrm{C}$, before exothermic pyrolysis begins. Leaf and woody plant tissue were studied. The emissions measured are used to infer their influence on fire propagation. The VOC emissions are then compared with emissions from smoldering combustion, which constitutes a large, difficult to characterize VOC source. The emissions are finally applied to charcoal production, a globally significant form of biomass burning.

Correspondence to: J. P. Greenberg

(greenber@ucar.edu)

(C) 2006 Author(s). This work is licensed under a Creative Commons License. 


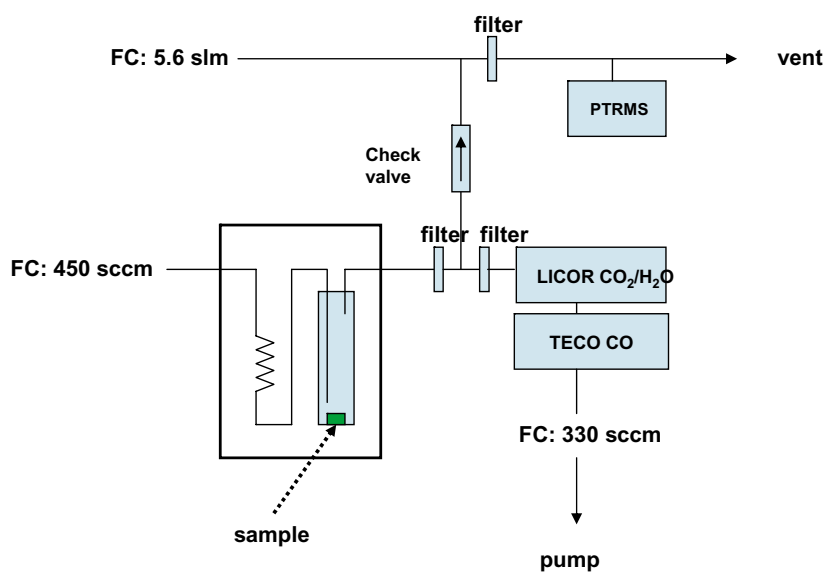

Fig. 1. Experimental setup. Preheated air (or nitrogen) flowed through a cold finger that contained the vegetation sample. The apparatus sat within a temperature programmed oven. The sample flow was measured undiluted by $\mathrm{CO}_{2}$ and $\mathrm{CO}$ analyzers. Flow was diluted further for PTRMS analysis. Glass fiber filters were placed before analyzers to trap condensable tars.

\section{Experimental information}

\subsection{Experimental setup}

The experimental setup is shown schematically in Fig. 1. Vegetation samples were placed at the bottom of a roasting chamber (100 ml Pyrex cold finger). Purge gas was introduced through the central tube and flow exited through the side tube. Gas flow through the chamber was controlled by a mass flow controller (Unit Instrument Company, Yorba Linda, CA). A gas chromatograph oven (model HP5880A, Hewlett-Packard, Palo Alto, CA) was used to enclose and control the temperature of the roasting chamber. Purge gas was preheated through a stainless steel coil $(2.2 \mathrm{~mm} \mathrm{ID} \times 4 \mathrm{~m})$, which also sat within the oven. The effluent flow was split into 2 streams: one went directly to analyzers for $\mathrm{CO}_{2}$ and $\mathrm{CO}$; the flow rate through this branch was controlled by the mass flow controller of the CO instrument. The second branch was diluted further (approximately 8:1) with purge gas flow by way of another mass flow controller; an aliquot of this flow was continuously sampled for VOCs by proton transfer reaction mass spectrometry. Filters (PallGelman glass fiber Acrodisc, $1 \mu \mathrm{m}$ pore size) were placed at several points in the sample flow path to trap condensable products (tars) before they entered the analytical instruments. All sample lines were Teflon.

The oven was programmed from $30^{\circ} \mathrm{C}$ to $300^{\circ} \mathrm{C}$ (higher temperatures were avoided to preclude exothermic pyrolysis) at a program rate of $10^{\circ} \mathrm{C} / \mathrm{min}$, with initial and final temperature holds of 2 and $15 \mathrm{~min}$, respectively. Only ultra-high purity air or nitrogen was used.

\subsection{Vegetation}

Experiments were conducted with leaf material from 5 species: Gamble oak (Quercus gambelli), ponderosa pine (Pinus ponderosa), eucalyptus (Eucalyptus saligna), sugar cane (Saccharum officinarum), and rice (Oriza sativa) and woody plant tissue from 2 species ( $P$ ponderosa, $E$ saligna). Plant species were chosen to represent genera in landscapes frequently consumed by wildfires or agricultural burning.

Typically three experiments were made with each species in air and one in nitrogen. E. saligna, Q. gambelli, $O$. sativa and $S$. officinarum leaves were harvested from young greenhouse-grown plants; $P$. ponderosa needles and wood were harvested from a mature tree growing outside in Boulder, CO. Green woody tissue from a greenhousegrown, juvenile $E$ saligna was also tested. Vegetation samples were cut from living vegetation. The fresh cuttings were weighed to the nearest $0.1 \mathrm{mg}$. Three additional cuttings were weighed fresh, then placed in drying oven $\left(60^{\circ} \mathrm{C}\right)$ overnight, then reweighed to allow for the calculation of the moisture content of vegetation tested. After experiments, the residue left in the roasting chamber was also weighed.

\subsection{Proton transfer reaction mass spectrometry (PTRMS)}

PTRMS was used to measure many VOCs produced in the roasting process. The lab-built instrument has been described in detail previously (Hanson et al., 2002). In the technique, a proton (from $\mathrm{H}_{3} \mathrm{O}^{+}$) was transferred to the $\mathrm{VOC}$ reactant by soft collision in a drift tube and the resulting ion passed through an orifice into a quadrupole mass spectrometer. Selected masses, corresponding to sample VOCs (parent or fragments ions), were monitored and quantified.

Calibration of responses for target VOCs were determined by several methods. When accurate and stable compressed gas mixtures containing target VOCs were available (acetonitrile, isoprene, terpenes, benzene, toluene), these were diluted to sample concentration ranges with a dynamic dilution system. For some VOCs (methanol, acetaldehyde, and acetone), calibrated permeation tubes (VICI Metronics, Poulsbo, WA) were used in a permeation tube calibration system (Kintek, La Marque, TX) to produce desired concentrations. For VOCs where no authentic standards were available, responses were calculated using measured PTRMS transmission characteristics and rate constants for the ion reaction of VOC with water ion clusters (Warneke et al., 2003).

\subsection{Gas chromatography-mass spectroscopy (GCMS)}

For each vegetation roasting experiment, VOCs were also determined by GCMS (Hewlett-Packard model 5971MS/5890GC, Palo Alto, CA). Samples were collected into electropolished stainless steel canisters when oven temperatures were $250-300^{\circ} \mathrm{C}$. Canisters were flushed with PTRMS sample stream air for several minutes before sample 
flow was captured. Samples were analyzed according to methods previously described (Greenberg et al., 1999).

\subsection{Carbon dioxide $\left(\mathrm{CO}_{2}\right)$}

$\mathrm{CO}_{2}$ was analyzed continuously by a non-dispersive infrared analyzer (model 6262, LICOR Inc, Lincoln, NE) connected in series with the undiluted sample outflow. Sample air was pulled through the analyzer at atmospheric pressure and at constant rate (by way of the pump and flow controller of the downstream $\mathrm{CO}$ instrument). $\mathrm{CO}_{2}$ concentrations were calibrated against a commercially prepared compressed gas standard (1428 ppm CO $\mathrm{CO}_{2}$, Scott Specialty Gases, Plumsteadville, PA).

\subsection{Carbon monoxide (CO)}

$\mathrm{CO}$ in undiluted sample flow was measured by IR absorption (Thermo Electron Corp., Model 48, Franklin, MA). CO concentrations were calibrated against NIST SRM\#2612a.

\subsection{Thermo-gravimetric analysis (TGA)}

$Q$. gambelli oak leaf and $P$. ponderosa needle samples were analyzed by thermo-gravimetric analysis (Cahn Instruments, model TGA 131 thermo-graphic analyzer, ThermoElectron Corp., Newington, MA), which tracks mass loss of samples as a function of temperature. Ten to $60 \mathrm{mg}$ of sample were placed in the microbalance of the TGA and heated at $10^{\circ} \mathrm{C} / \mathrm{min}$ from room temperature to $700^{\circ} \mathrm{C}$. The decrease in mass and the rate of change of mass as a function of temperature were recorded. The heating was carried out in a $450 \mathrm{ml} / \mathrm{min}$ flow of air or nitrogen in separate experiments.

\section{Results}

\subsection{GCMS}

VOCs emitted during the heating of the vegetation were analyzed and components identified by GCMS. Emissions were dominated by oxygenated volatile organic compounds. Major emissions from the five species studied were largely the same and include (in order of molecular weight) methanol, acetonitrile, acetaldehyde, acetone, acetic acid, furan, acetol, pyrazine, 2,3 butadione, phenol, furylaldehyde, benzaldehyde, and terpenes. No major alkane, alkene or aromatic emissions were observed by GCMS or PTRMS at these temperatures, consistent with the physics of the pyrolysis process (Yokelson et al., 1996). It is likely that some VOCs, especially oxygenated VOCs, were not efficiently transferred from canisters to the GCMS system (Friedli et al., 2001). The GCMS method only allowed for the measurement of VOCs eluting between butane and pentadecane. Consequently, several VOC emissions reported previously (e.g., ethene and

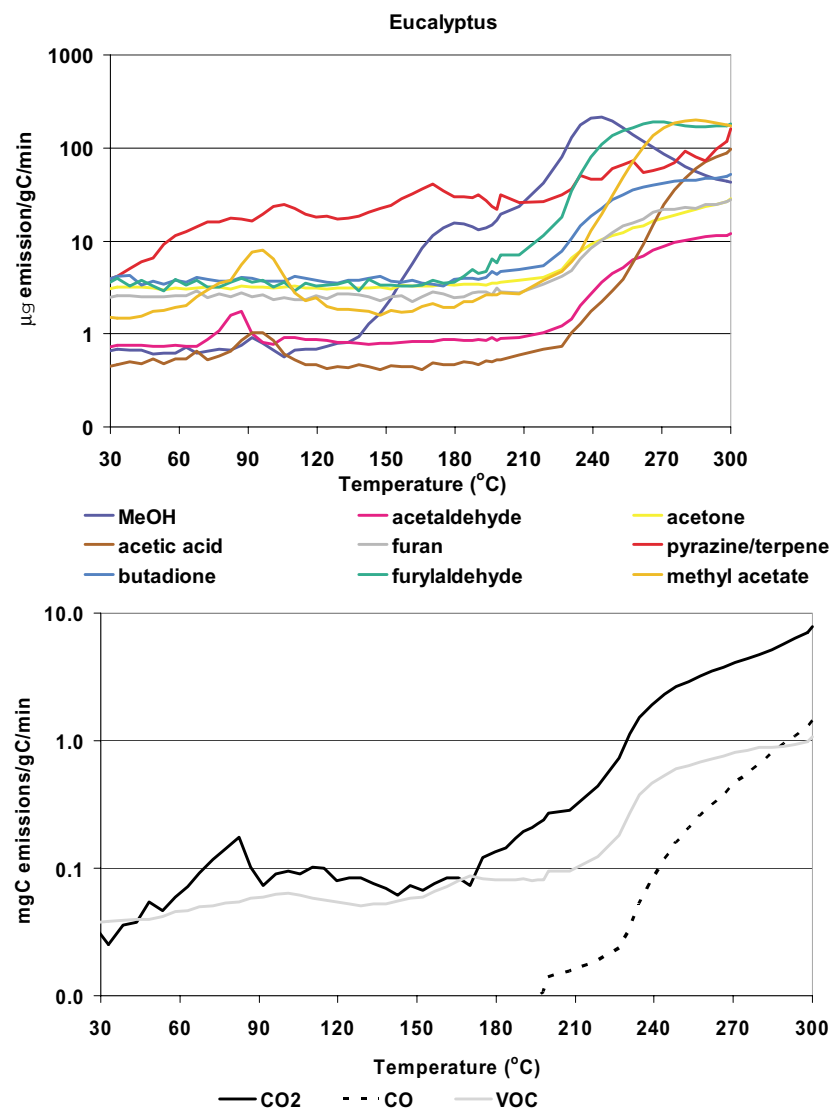

Fig. 2. Emission factors $(\mu \mathrm{gC} / \mathrm{gC})$ of the most abundant VOCs emissions versus temperature (top panel) and total $\mathrm{VOC}, \mathrm{CO}_{2}$ and $\mathrm{CO}$ emission (lower panel) for Eucalyptus leaf tissue.

propene) were not measured in these experiments. Quantitative GCMS analysis was not made for samples from canisters.

\subsection{PTRMS, $\mathrm{CO}_{2}$, and $\mathrm{CO}$}

Individual ions for PTRMS analysis were selected through comparison with GCMS analyses. Emissions of VOCs from E. saligna are shown in Fig. 2, which also includes results for $\mathrm{CO}$ and $\mathrm{CO}_{2}$ experiments conducted simultaneously with PTRMS experiment. In all experiments, $\mathrm{CO}_{2}$ emissions were greater than $\mathrm{CO}$ and total VOC emissions. At lower temperatures, VOC emission rates exceed those for $\mathrm{CO}$, but near the higher temperature limit $\left(300^{\circ} \mathrm{C}\right) \mathrm{CO}$ and VOC emission rates were approximately the same. Emissions for most VOCs have similar temperature profiles for the 5 vegetation species (Fig. 3). (Q. gambelli oak was not tested for acetic acid, acetol, phenol or benzaldehyde emissions; P. ponderosa was not tested for benzaldehyde emissions.)

Emissions from woody plant tissue ( $P$. ponderosa and E. saligna) are shown in Fig. 4; the identities and emission 

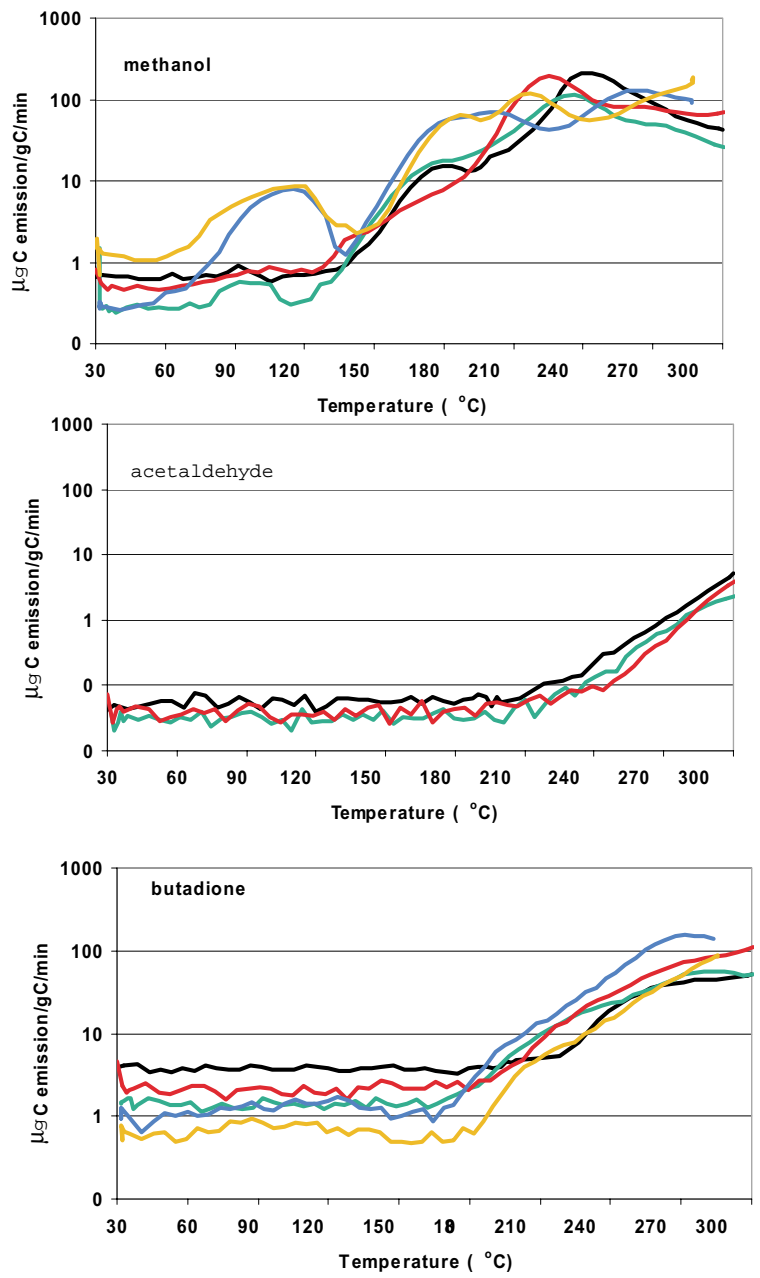

$-E$ saligna $-Q$ gambelli $-P$ ponderosa $-S$ officinarum $-O$ sativa

Fig. 3. Comparison of emission factors (top: methanol, middle: acetone; bottom: 2,3-butadione) versus temperature for leaf tissue of $Q$ gambelli, $P$ ponderosa, E saligna, $S$ officinarun, and $O$ sativa.

factors of most VOC emissions from woody tissue were similar to those found for leaf tissue, although emission factors for some VOCs were higher in one or the other.

The ion detected $(\mathrm{m} / \mathrm{z})$ by PTRMS may correspond, in some cases, to more than one possible VOC emission. Acetone, glyoxal, and methylvinylether are detected as $\mathrm{m} / \mathrm{z} 59$ in PTRMS. GCMS analysis indicated that acetone was the major component detected at $\mathrm{m} / \mathrm{z}$ 59. Christian et al. (2004) also found that acetone was the major emission from laboratory studies of various fuels.

Acetic acid and glycolaldehyde both are detected at $\mathrm{m} / \mathrm{z}$ 61. GCMS analysis of pyrolysis emissions indicated only acetic acid was present (the suitability of the analytical method for glycolaldehyde was not tested). The acetic acid emission factor, however, may be, on average, six times that of glycolaldehyde (Christian et al., 2004). Similarly, furan

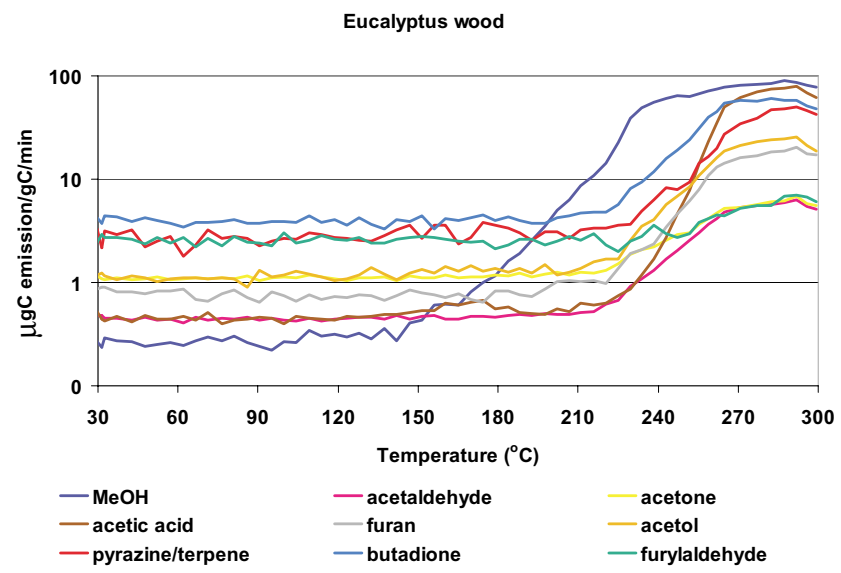

Fig. 4. Emission factors $(\mu \mathrm{gC} / \mathrm{gC})$ of the most abundant VOCs emissions versus temperature for Eucalyptus woody tissue.

and isoprene are detected as $\mathrm{m} / \mathrm{z} 69$ in PTRMS. Isoprene is emitted immediately after it is produced by certain plant species exposed to sufficient sunlight; it is not stored in the leaf or woody tissue. The experiments described here were conducted in the darkness of the oven; consequently, no isoprene was likely produced. Isoprene was not detected in the GCMS analysis, while furan was easily identified. Although isoprene has been reported as an emissions from fires, its emission factor is 4 to 10 times less than furan (Andeae and Merlet, 2001). Acetol (hydroxyacetone) and methyl acetate are both detected as $\mathrm{m} / \mathrm{z} 75$ in PTRMS. GCMS analysis could not identify either product with adequate certainty. Christian et al. (2004) reason that acetol is the major emisison product, however.

In the following discussion and acompanying tables and figures, the major VOC will be used to represent the $\mathrm{m} / \mathrm{z}$ of detection, but it should be understood that minor contributions from other VOCs may be included also.

\subsection{TGA}

Qualitatively, the patterns from TGA for $Q$. gambelli and the P. ponderosa are similar (Fig. 5). Water and some stored organic compounds are distilled below $150^{\circ} \mathrm{C}$. Between approximately $150^{\circ} \mathrm{C}$ and $360^{\circ} \mathrm{C}$, VOCs, $\mathrm{CO}$ and $\mathrm{CO}_{2}$ are released in both nitrogen and air and correspond to the pyrolysis (pyrolytic decomposition) of hemicellulose and cellulose in the vegetation. Above $360^{\circ} \mathrm{C}$, the behavior of the processes in air and nitrogen diverge. In air, exothermic pyrolysis proceeds with additional $\mathrm{CO}_{2}$ and $\mathrm{CO}$ emitted between 400 and $600^{\circ} \mathrm{C}$; above $600^{\circ} \mathrm{C}$ only ash remains. A minor, undertermined contribution of oxygenated VOCs may also result from the oxidation of pyrolytically produced VOCs. In nitrogen, there is apparently little release of $\mathrm{CO}$ and $\mathrm{CO}_{2}$ at the temperatures above $400^{\circ} \mathrm{C}$ because chemisorption of oxygen is needed to promote gasification of the fuel (Yokelson et al., 1996, Fig. 7). 

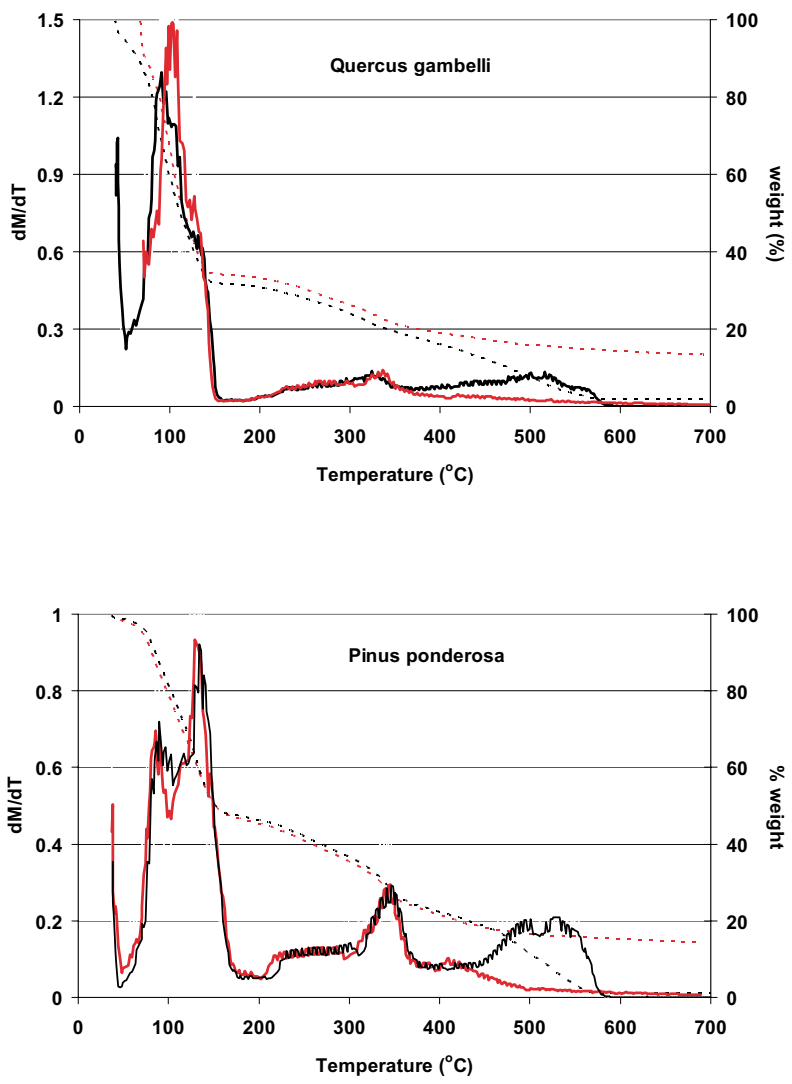

Fig. 5. Thermo-gravimetric analysis of P. ponderosa needle and $Q$. gambelli leaf tissue. Experiments were made in air (black line) and nitrogen (red line). Shown are the rate of change of mass with time (solid line, left scale) and percent weight remaining (dotted line, right scale). Distillation emissions occurred before $175^{\circ} \mathrm{C}$, followed by endothermic pyrolysis emissions (up to approximately $350^{\circ} \mathrm{C}$ ). Additional emissions from exothermic pyrolysis occurred at higher temperatures. Results were similar for both air and nitrogen, except at temperatures greater than $400^{\circ} \mathrm{C}$, where the presence of oxygen produces additional $\mathrm{CO}_{2}$ and $\mathrm{CO}$ emissions.

\subsection{Mass balance}

Table 1 compiles data for the initial moisture content, emissions and residue after heating. Tar collected on the filters was not weighed and is, therefore, not included in the mass balance. The carbon content of the residue was not determined analytically, but was computed to achieve mass balance (assuming that the contribution of tars was negligible). The residue of the air and nitrogen experiments had approximately the same carbon content.

\subsection{Emission rate uncertainties}

Calibrations for several of the VOCs determined (acetonitrile, terpenes) were made from compressed gas standards; the concentration of these standards was confirmed in comparison with other compressed gas standards using GC-FID
Table 1. Mass balance.

\begin{tabular}{|c|c|c|c|c|}
\hline & & $\%$ moisture $^{1}$ & $\%$ emissions $^{2}$ & $\% \mathrm{C}$ residure ${ }^{2}$ \\
\hline \multirow[t]{2}{*}{ Q. gambelli, } & air & 51 & 5 & 78 \\
\hline & $\mathrm{N}_{2}$ & & 3 & 74 \\
\hline \multirow[t]{2}{*}{ P. ponderosa, } & air & 59 & 9 & 94 \\
\hline & $\mathrm{N}_{2}$ & & 3 & 86 \\
\hline \multirow{2}{*}{ E. saligna, } & air & 54 & 6 & 72 \\
\hline & $\mathrm{N}_{2}$ & & 4 & 73 \\
\hline \multirow[t]{2}{*}{ S. officinarum, } & air & 83 & 7 & 58 \\
\hline & $\mathrm{N}_{2}$ & & 4 & 65 \\
\hline \multirow[t]{2}{*}{ O. sativa, } & air & 77 & 15 & 90 \\
\hline & $\mathrm{N}_{2}$ & & 7 & 94 \\
\hline
\end{tabular}

$1\left(\mathrm{gH}_{2} \mathrm{O} / \mathrm{g}\right.$ fresh weight $) \times 100 \%$

$2(\mathrm{gC}$ residue/gC dry weight $) \times 100 \%$

(Apel et al., 1994). The accuracy of these standards was judged to be within 5\%. For methanol, acetaldehyde and acetone, calibrations were made with respect to calibrated permeation tubes. Permeation tubes were weighed periodically to determine the mass emission rate of the VOCs. The tube emission rates determined agreed within $10 \%$ of the emission rates specified by the supplier.

In the cases of most VOCs measured by PTRMS, no primary standard was available. For these VOCs the concentrations were calculated (after Warneke et al., 2003) using literature rate constants for the reaction of the VOC with $\mathrm{H}_{3} \mathrm{O}^{+}$, mass spectrometer transmission characteristics (determined experimentally), and the reaction time within the drift tube. Since most VOCs have a reaction rate with $\mathrm{H}_{3} \mathrm{O}^{+}$determined by collision rate, the rate constants for the reactions are similar and an average rate constant was used when none was available from literature (Spanel and Smith, 1999, and references therein). The uncertainty associated with concentration estimates for these VOCs may be as large as a factor of 2.

Any losses of VOCs in the experimental system were assumed negligible for the VOCs reported here. Higher molecular weight VOCs (tars) that condensed on filters were not measured; their contribution to the total VOC emission factor is therefore not included.

Calibration for $\mathrm{CO}_{2}$ was made using a primary standard of $\mathrm{CO}_{2}$ in air $(1430 \pm 20 \mathrm{ppm}$, Scott Specialty Gases, Plumsteadville, PA). The concentrations determined were estimated to be accurate to within 5\%. CO determinations were made with respect to NIST SRM \#2612a $(9.6 \pm 0.12 \mathrm{ppm}$ $\mathrm{CO}$ in nitrogen); uncertainties were estimated to be approximately $10 \%$.

Mass flow meters were calibrated against bubble flow meters for the lower flow ranges $(<500 \mathrm{sccm})$ and against a wet test meter (Precision Scientific CO, Chicago, IL) for higher flows. The uncertainties in flows are less than a few percent. Fresh and dry leaf or wood tissue was measured to the 
nearest $0.1 \mathrm{mg}$ for 3 samples of each species to determine moisture content; the uncertainty of the moisture content is within $10 \%$.

Errors were propagated using uncertainties in flow rates, vegetation moisture content and calibration standards. The errors in the emission rates for methanol, acetaldehyde and acetone (determined from permeation tubes) were approximately $15 \%$; for terpenes and acetonitrile, where a dynamic dilution of flow from a compressed gas standard produced calibration mixtures, the uncertainty was also on this order. In the case of those VOCs whose concentrations were calculated from rate constants and ion transmission properties of the PTRMS, the uncertainties in the emissions rates were dominated by the uncertainty in the calculation of response factors and were probably on the order of a factor of 2 . Uncertainties in $\mathrm{CO}_{2}$ and $\mathrm{CO}$ emissions are estimated to be approximately $15 \%$.

\section{Discussion}

\subsection{Combustion process}

Combustion may be divided into several phases (Browne, 1958; Yokelson et al., 1996), each with distinct emissions and emission rates. Distillation occurs at temperatures up to $200^{\circ} \mathrm{C}$; water, methanol, terpenes and other VOCs stored in liquid pools are emitted during distillation. These emissions are the largest weight loss fraction, since they include water, which represented $50-80 \%$ of the weight of fresh vegetation (Table 1). Endothermic, low temperature pyrolysis (thermal degradation of organic compounds) takes place between 200 and $280^{\circ} \mathrm{C}$; methanol, acetic acid, and other oxygenated VOCs are released during this stage. Significant emissions of $\mathrm{CO}_{2}$ and $\mathrm{CO}$ from the breakdown of hemicellulose and cellulose also occur during endothermic pyrolysis (Fig. 2). Between 280 and $500^{\circ} \mathrm{C}$, exothermic pyrolysis occurs; a combustible mixture of non-methane hydrocarbons and tars are emitted, but were not quantified or identified in the experiments.

Additional $\mathrm{CO}_{2}$ and $\mathrm{CO}$ emissions observed between 400 and $600^{\circ} \mathrm{C}$ are produced in exothermic pyrolysis reactions involving oxygen and are not seen in the TGA nitrogen experiments (Fig. 5). In both air and nitrogen, water vapor emitted comes not only from distillation of stored water but also from dehydration of cellulose during pyrolysis. Consequently, the residue of pyrolysis has a higher carbon percent composition than the fresh vegetation (approximately $44 \%$ by weight for cellulose). The residue (Table 1) was calculated to be enriched to 50-70\% carbon for $Q$. gambelli, E. saligna and $P$. ponderosa leaf tissue, but enriched to over $80 \%$ for $S$. officinarum and $O$. sativa leaf tissue. At high carbon enrichment, the residue is called charcoal. Charcoal, a black-body radiation absorber, has a low temperature of spontaneous ignition compared to other pyrolysis products. Reactions among py- rolysis products and with oxygen may be catalyzed by charcoal (Browne, 1958).

An ignition point is finally reached when the process becomes exothermic and flaming combustion begins. Aromatic, olefinic and aliphatic organic compounds are released in the flaming stage, along with additional $\mathrm{CO}$ and $\mathrm{CO}_{2}$. After flaming is extinguished, smoldering combustion continues (Yokelson et al., 1997; Bertschi et al., 2003a).

Oxygenated VOCs are almost exclusively released during the distillation and pyrolysis processes; their emission factors, consequently, may be most easily measured during these phases alone. Presumably, aromatic and aliphatic hydrocarbon emission factors may be measured during the flaming phase (in a similar TGA experiment, for example).

\subsection{Emission comparison among species}

For most VOCs, emissions were lowest at the lowest temperatures and highest near $300^{\circ} \mathrm{C}$ (Fig. 3). Methanol, acetaldehyde, acetone, acetic acid and acetol had local maxima between 90 and $120^{\circ} \mathrm{C}$; from TGA (Fig. 5) and PTRMS (Fig. 2) analyses, we assume that water and these VOCs were present in fresh plant tissue and were distilled early in the temperature program $\left(60-150^{\circ} \mathrm{C}\right)$. Most other emissions occurred at significantly higher temperatures $\left(200-300^{\circ} \mathrm{C}\right)$. Several VOCs showed at least 2 local maxima in emissions up to $300^{\circ} \mathrm{C}$, indicating that their emission may have more than one source. For example, methanol is both present initially as a dissolved component in leaf water and also is released in the de-methylation of pectin at higher temperatures (Fall, 1999). The two grasses, $S$. offcinarum and $O$. sativa, emitted little furylaldehyde compared to leaves from the woody plant species. O. sativa emitted more acetic acid than other species, while $P$. ponderosa emitted more terpene and phenol. $Q$ gambelli also emitted significantly more furyl aldehyde.

Pyrazine and terpenes both give the characteristic $\mathrm{m} / \mathrm{z} 81$ in PTRMS analysis. For $Q$. gambelli, O. sativa, and $S$. officinarum, the ion represents pyrazine exclusively, since these species do not have stored terpenes. For $P$. ponderosa and E. saligna, which contain stored terpenes, $\mathrm{m} / \mathrm{z} 81$ probably represents terpene at temperatures below $200^{\circ} \mathrm{C}$ and a mixture of pyrazine and terpenes at higher temperatures. Near $300^{\circ} \mathrm{C}, \mathrm{CO}_{2}$ was the largest component of emissions; $\mathrm{CO}_{2}$ emissions were also detected even at the lowest temperatures of the experiments.

For all species, VOC emissions in the temperature range $30-300^{\circ} \mathrm{C}$ were approximately the same in pattern and magnitude in air and nitrogen experiments. The exception was found for furylaldehyde, which was emitted from the grasses at a significantly higher rate in nitrogen than air. The ratio of VOCs to $\mathrm{CO}_{2}$ emissions is higher in the nitrogen experiments, while the ratio of $\mathrm{CO}$ to $\mathrm{CO}_{2}$ remains approximately the same (Table 2). Pyrolysis of plant tissue in oxygen likely contributes to additional $\mathrm{CO}_{2}$ and $\mathrm{CO}$ emissions. 
TGA analyses indicated additional emissions of VOCs up to $350^{\circ} \mathrm{C}$, above which no substantial emissions were seen until approximately $500^{\circ} \mathrm{C}$. The additional emissions between 300 and $350^{\circ} \mathrm{C}$ were assumed to be comprised of the same VOCs emitted at $300^{\circ} \mathrm{C}$, since many VOCs had near their maximum emissions at about $300^{\circ} \mathrm{C}$. Emissions above $500^{\circ} \mathrm{C}$ are probably $\mathrm{CO}_{2}$ and $\mathrm{CO}$ emissions from the reaction of oxygen with organic material, since these emissions were not seen in the nitrogen experiments.

Some VOCs may not have been measured by PTRMS because parent or fragment ions were not monitored during experiments or because the PTRMS technique was not sensitive to those VOCS (e.g., alkanes). Additional VOCs identified in GCMS analyses were not quantified. The GCMS analysis range was from butane to approximately penta-decane. Tars, which were collected on filters, are not included in the emission totals, nor are any VOCs which may not have been transferred through the Teflon sample tubing (although any loss was likely negligible). Several VOC emissions previously reported for pyrolysis and distillation of leaf and wood tissue were not measured or quantified. For example, Yokelson et al. (1996) reported emission factors for the distillation and pyrolysis stages for formaldehyde in laboratory experiments. The mass balance computed in Table 1 gives a similar percentage carbon in residue as reported for charcoal (Pennise et al., 2001); it is assumed, therefore, that VOC emissions measured comprise the major weight fraction of total emissions (Table 2).

Emission factors ( $\mathrm{mgC} \mathrm{VOC} / \mathrm{kgC}$ fuel dry weight) for the distillation and pyrolysis of the vegetation species studied are given in Table 3.

\subsection{Comparison of leaf and woody tissue emissions}

Woody tissue is composed primarily of hemicellulose, cellulose and lignin; leaves are composed largely of hemicellulose and cellulose. Hemicellulose decomposes between 200 and $260^{\circ} \mathrm{C}$, followed by cellulose at 240 to $350^{\circ} \mathrm{C}$, and finally by lignin at 280 to $500^{\circ} \mathrm{C}$ (Browne, 1958). Consequently, the major emissions (in the temperature range $30-300^{\circ} \mathrm{C}$ ) from woody tissues (Fig. 4) were similar in identity and magnitude to the emissions from leaf tissues for E. saligna and P. ponderosa. However, there are several exceptions. Methanol and acetic acid emission factors from the pyrolysis of P. ponderosa and E. saligna woody tissue are similar to those reported previously for smoldering woody tissue, but were significantly higher than emission factors measured for leaf tissue (Table 3). Furylaldehyde has a much higher emission factor in P. ponderosa wood than in needles, but, on the contrary, furylaldehyde emissions from E. saligna wood were much lower than emissions from the leaves. Woody plant tissue for both species had much lower terpene/pyrazine $(\mathrm{m} / \mathrm{z}$ 81) emissions than leaves or needles; this may result from the lower nitrogen content or the smaller percentage of terpenes in woody tissue compared to leaf tissue.
Table 2. emission ratios ( $\mathrm{gC}\left(\mathrm{CO}_{2}\right): \mathrm{gC}(\mathrm{CO}): \mathrm{gC}$ (VOC).

\begin{tabular}{lll}
\hline & Air & Nitrogen \\
\hline Q. gambelli & $100: 10: 14$ & $100: 10: 20$ \\
P. ponderosa & $100: 15: 33$ & $100: 5: 61$ \\
E. saligna & $100: 12: 26$ & $100: 16: 44$ \\
S. officinarum & $100: 14: 12$ & $100: 14: 25$ \\
O. sativa & $100: 16: 8$ & $100: 13: 21$ \\
P. ponderosa (wood) & $100: 16: 19$ & \\
E. saligna (wood) & $100: 17: 7$ & \\
\hline
\end{tabular}

\subsection{Fire induced emissions in forest canopies}

Fire propagates when fuel is heated to a temperature where its volatile emissions are of sufficient concentration that they may be ignited by an attached flame, glowing embers, or other adequate energy source. In typical fires, biomass is heated to temperatures on the order of $1100^{\circ} \mathrm{C}$ and a large fraction may be gasified at a high rate. Ignition of these emissions may also ignite another volume of gas below the flammability threshold. In the present focus on low temperature distillation and pyrolysis emissions, the concentration of emissions during these combustion phases may be estimated as a function of heating time to determine how quickly concentrations may reach levels where they may be ignited.

The leaf biomass in mature forests has been estimated at approximately $750 \mathrm{gm}^{-2}$, with most of the foliage at some level near the middle of the canopy (Guenther et al., 1995). For a well-mixed volume of the mid-canopy $\left(1 \mathrm{~m}^{3}\right)$ containing $250 \mathrm{~g}$ of foliage (upper limit to what may be expected) heated at $300^{\circ} \mathrm{C}$ for $1 \mathrm{~min}$, emission concentrations of $<0.02 \%$ (volume emissions/volume of air) would result, much lower than the lower flammability limits of individual VOCs in Table 4. Advection in the pre-flaming forest on the order of $10 \mathrm{~ms}^{-1}$ (Taylor et al., 2004) would significantly reduce the time for heating and decrease concentrations, even if advected air is from adjacent volumes also heated to $300^{\circ} \mathrm{C}$. However, concentrations of emissions near leaves may be considerably higher than the average for a well-mixed volume of the canopy. Assuming a specific leaf mass of $233 \mathrm{gm}^{-2}$ for $P$ ponderosa and $75 \mathrm{gm}^{-2}$ for $Q$ gambelli and $E$ saligna (Geron et al., 1994), a $1 \mathrm{~mm}$ leaf boundary layer, low turbulence and $300^{\circ} \mathrm{C}$, concentration approaching $2 \%(\mathrm{v} / \mathrm{v})$ may be reached in 20,50 , and $180 \mathrm{~s}$ for $P$ ponderosa, E saligna and $Q$ gambelli, respectively. Hence, combustible mixtures may be produced at temperatures below $350^{\circ} \mathrm{C}$, much lower than the temperature of exothermic pyrolysis. The result is also consistent with that of Dimitrakopoulos (2000), who, from TGA measurements of mean volatization rates, concluded that Pinus species should be more combustible than Quercus species. 
Table 3. Comparison with previously reported emission factors ( $\mathrm{gC}$ emissions/kgC fuel).

\begin{tabular}{|c|c|c|c|c|c|c|c|}
\hline \multirow{3}{*}{$\mathrm{gC} / \mathrm{kgC}$} & \multicolumn{7}{|c|}{ this work } \\
\hline & \multicolumn{5}{|c|}{ leaves } & \multicolumn{2}{|r|}{ wood } \\
\hline & oak & ponderosa & eucalyptus & sugar cane & rice & ponderosa & eucalyptus \\
\hline methanol & 3 & 5 & 4 & 3 & 5 & 10 & 5 \\
\hline acetonitrile & 0.06 & 0.09 & 0.04 & 0.3 & 0.3 & 0.2 & 0.04 \\
\hline acetaldehyde & 0.3 & 0.3 & 0.3 & 0.3 & 0.5 & 1 & 0.3 \\
\hline acetone $^{1}$ & 0.5 & 0.7 & 0.7 & 0.5 & 1 & 2 & 0.4 \\
\hline acetic acid ${ }^{2}$ & 9 & 1 & 3 & 14 & 5 & 2 & \\
\hline furan & 1 & 2 & 0.7 & 1 & 1 & 3 & 0.8 \\
\hline acetol $^{3}$ & & 12 & 3 & 4 & 6 & 3 & 1.1 \\
\hline pyrazine/terpene $e^{4}$ & 2 & 11 & 4 & 2 & 1 & 6 & 2 \\
\hline butadione & 2 & 5 & 1 & 2 & 1 & 7 & 0.9 \\
\hline phenol & & 7 & 2 & 0.5 & 0.3 & 2 & 14 \\
\hline furyl aldehyde & 8 & 4 & 5 & 1 & 1 & 39 & 0.7 \\
\hline \multirow[t]{2}{*}{ benzaldehyde } & & 15 & 1 & 0.3 & 0.1 & 5 & 3 \\
\hline & \multicolumn{7}{|c|}{ previous reports } \\
\hline \multirow[t]{2}{*}{$\mathrm{gC} \mathrm{kgC}^{-1}$} & cooking & charcoal & wood & smoldering & \multicolumn{3}{|c|}{ literature review ${ }^{5}$} \\
\hline & fires $^{6}$ & $\operatorname{kiln}^{6}$ & fuels $^{7}$ & wood $^{8}$ & grasses & forest & charcoal production \\
\hline methanol & 3 & 9 & 2 & 5 & 1 & 2 & 0 \\
\hline acetonitrile & & & 0.4 & & 0.1 & 0.2 & \\
\hline acetaldehyde & & & 1 & & 0.5 & 0.7 & \\
\hline acetone $^{1}$ & & & & 0.5 & 0.5 & 0.6 & 1 \\
\hline acetic acid ${ }^{3}$ & 3 & 4 & 2 & 2 & 1 & 2 & 1 \\
\hline furan & 0.3 & 1 & 0.3 & 1 & 0.1 & 0.5 & \\
\hline acetol $^{2}$ & & & 4 & & & & \\
\hline phenol & 3 & 2 & 1 & 2 & 0.003 & 0.006 & \\
\hline 2,3 butadione & & & & & 0.6 & 0.9 & \\
\hline
\end{tabular}

1 may include methylvinylether $(<20 \%)$

2 may include glycholaldehyde $(<20 \%)$

3 may include small contribution from methyl acetate

4 compute as if $100 \%$ pyrazine

5 Andreae and Merlet (2001)

${ }^{6}$ Bertschi et al. (2003a), Zambia RSC

${ }^{7}$ Christian et al. (2003), Indonesian and African fuels, average

${ }^{8}$ Bertschi et al. (2003b), smoldering, various domestic fuels

Emission contributions from reservoirs, such as sap (in branches or trunk), were not included in the flammability estimate. The estimate also does not include contributions from any VOC emissions from woody tissue. The ratio of leaf biomass to twig biomass (diameter $<5 \mathrm{~mm}$ ) has been estimated at 2:1 for Picea (spruce) and 1:1 for Populus (balsam poplar) species (Yarie and Meade, 1988). Twigs and leaves both are expected to heat rapidly in front of fires and the inclusion of emissions from twigs may increase the concentrations of VOCs produced and reduce the time for the generation of flammable mixtures.

\subsection{Smoldering combustion}

Significant emissions of VOCs occur during smoldering combustion, after the flaming stage ends (Yokelson et al., 1997; Bertschi et al., 2003a). After flames have been extinguished, glowing zones continue to heat adjacent vegetation; the heating produces distillation and pyrolysis emissions.

Emissions from smoldering combustion are usually included with the emissions measured in smoke plumes (Andreae and Merlet, 2001); however, smoldering combustion may continue for several days after the active flaming stage. Smoldering has higher emission factors for oxygenated VOCs than the average factors measured in 
Table 4. Lower limit of flammability ${ }^{1}$.

\begin{tabular}{lc}
\hline VOC & $(\mathrm{v} / \mathrm{v} \%)$ \\
\hline Methanol & 7 \\
Acetonitrile & 3 \\
Acetaldehyde & 4 \\
Acetone & 3 \\
Acetic acid & 4 \\
Furan & 2 \\
Methyl acetate & 3 \\
Phenol & 2 \\
Furylaldehyde & 2
\end{tabular}

${ }^{1}$ Handbook of Chemistry and Physics

smoke plumes. Many emission inventories used in regional and global chemistry-transport models do not differentiate among the various stages of combustion and generally use emission factors for smoke plumes (Liousse et al., 2004). Emission factors for oxygenated VOCs are generally highly uncertain or not reported (Liousse et al., 2004) and, therefore, may not be included as emissions in biomass burning emission inventories.

\subsection{Emissions from charcoal production}

Charcoal fuel production typically proceeds with a large volume of organic material (logs, branches, slash) either loaded into a kiln or simply covered with earth. Heat is applied from some external source and heated air $\left(350-400^{\circ} \mathrm{C}\right)$ is circulated through the organic matter (Lacaux et al., 1994). At these temperatures, distillation and pyrolysis emissions are the largest fraction of VOC emissions from charcoal production (Fig. 5). The carbon content of the residue of the experiments (approximately 70-90\% for leaves from woody plants, Table 1) is similar to the carbon content of about $75 \%$ for typical charcoal production kilns (Pennise et al., 2001). The emission factors for several VOCs are in agreemnet with previous reported results for charcoal production (Table 3).

Previous estimations of the total VOC emissions from charcoal production may be substantially underestimated. Pennise et al. (2001) calculated greenhouse gas contributions from charcoal production. Their results indicate that VOCs were equivalent to approximately $10 \%$ of the carbon emitted as $\mathrm{CO}_{2}$ in the production process. However, the carbon in VOC emissions may be as high as $30 \%$ of the carbon emitted as $\mathrm{CO}_{2}$ (Table 2), or even higher if VOCs detected but not quantified or unmeasured are included. Pennise et al. (2001) also report an average ratio of VOC emissions to $\mathrm{CO}$ emissions of approximately $0.4 \mathrm{~g} \mathrm{VOC} / \mathrm{g} \mathrm{CO}$; Bertschi et al. (2003b) indicate the ratio at approximately $0.3 \mathrm{~g} \mathrm{VOC} / \mathrm{g}$ CO. Measurements of the species in this study show that VOC emissions equal or exceed CO emissions (Table 2). Several possibilities may explain the higher ratio of VOC to
Table 5. Emissions from charcoal production (Tg pollutant $\left.\mathrm{yr}^{-1}\right)^{1}$.

\begin{tabular}{lccccc}
\hline Region & $\begin{array}{c}\text { charcoal } \\
\text { production }\end{array}$ & $\mathrm{CO}_{2}$ & $\mathrm{CO}$ & $\mathrm{CH}_{4}$ & $\mathrm{VOC}^{2}$ \\
\hline Africa & 10 & 15 & 2 & 0.4 & 2 \\
Asia & 9 & 13 & 1 & 0.2 & 2 \\
Latin America & 12 & 12 & 11 & 0.3 & 2 \\
\hline
\end{tabular}

1 after Yevich and Logan (2003)

2 this work

CO emissions found here. Pennise et al. (2001) employed a total hydrocarbon analyzer, which converts hydrocarbons to $\mathrm{CO}_{2}$, which alone is measured; since individual hydrocarbons and oxygenated hydrocarbons are not distinguished, the emission mass may only be estimated from an assumption of the average weight of organic compounds. For example, the ratio of the molecular weight of methanol to methane is $32: 16$; the ratio for 2,3 butadione to butane is $86: 58$; in that study, an average molecular weight of 18 was used, which underestimates the weights of some emissions, especially oxygenated VOCs. The Bertschi et al. (2003b) tecchnique did not measure several of the VOCs reported here. Actual kiln temperatures may reach temperatures much higher than $300^{\circ} \mathrm{C}$. Additional $\mathrm{CO}$ and $\mathrm{CO}_{2}$, but little VOC, is produced at high temperature (Fig. 5 and Yokelson et al., 1996). This would act to decrease the VOC to $\mathrm{CO}$ ratios in previous studies.

Yevich and Logan (2003) estimated global contribution of $\mathrm{CO}_{2}, \mathrm{CO}, \mathrm{CH}_{4}$ from charcoal production. The results of the experiments reported here suggest that VOC emissions from charcoal production are on the order of $\mathrm{CO}$ emissions in their estimate, much larger than previously estimated (Table 5).

\section{Conclusions}

The distillation and pyrolysis of leaf and woody tissue produce mostly the same VOCs with similar emission factors for most VOCs. The VOC emissions from these processes are mostly oxygenated hydrocarbons. The emissions are similar to those from smoldering combustion, a later stage of the combustion process. Emission factors for biomass burning are most often given for fire plumes, which integrate emissions from all stages of combustion. The emission factors for several oxygenated VOCs reported here are not described explicitly or are very uncertain in current biomass burning inventories. Since smoldering combustion may continue for an extended period after the end of flaming combustion, a separate treatment of smoldering combustion emissions is needed to include the effect of these reactive VOCs in regional and global air quality simulations. 
Calculations indicate that emissions from the distillation and pyrolysis of leaves mixed within the canopy caused by heat from nearby fires would not produce sufficiently high concentrations to reach the lower limit of flammability. However, emission concentrations may be much higher in the small volume around the vegetation under low turbulent conditions. Ignition may occur from a glowing ember originating in the fire front or from hot charcoal in the pyrolyzed canopy.

Emissions from charcoal production are rich in oxygenated VOCs, many of which participate very actively in atmospheric chemistry, producing ozone, other oxidants and carbon monoxide. The chemistry may not only have regional air quality implications, but may also have global effects on the organic carbon budget and the global warming potential of the emitted VOCs. Distillation and pyrolysis during charcoal production produce VOC emissions on the order of $\mathrm{CO}$ emissions and greenhouse gas contributions as high as $40 \%$ of the carbon emitted as $\mathrm{CO}_{2}$.

Acknowledgements. We wish to thank NCAR internal reviewers (G. Petrone and C. Wiedinmyer) and ACPD external reviewers (R. J. Yokelson and an anonymous reviewer) for very helpful comments. We also thank S. Nandi for her contributions to the study. The National Center for Atmospheric Research is opreated by the University Corporation for Atmospheric Research and is sponsored by the U.S. National Science Foundation.

Edited by: M. Ammann

\section{References}

Apel, E. C., Calvert, J. G., and Fehsenfeld, F. C.: The nonmethane hydrocarbon intercomparison experiment, J. Geophys. Res., 99(D8), 16 651-16 664, 1994.

Andreae, M. O. and Merlet, P.: Emissions of trace gases and aerosols from biomass burning, Global Biogeochem. Cycles, 15(4), 955-966, 2001.

Bertschi, I., Yokelson, R. J., Ward, D. E., Babbitt, R. E., Susott, R. A., Goode, J. G., and Hao, W. M.: Trace gas and particle emissions from fires in large diameter and belowground biomass fuels, J. Geophys. Res., 108(13) 8472, doi:10.1029/2002JD002100, 2003a.

Bertschi, I., Yokelson, R. J., Ward, D. E., Christian, T. J., and Hao, W. M.: Trace gas emissions from the production and use of domestic biofuels in Zambia measured by open-path Fourier transform infrared spectroscopy, J. Geophys. Res., 108(D13), 8469, doi:10.129/2002JD002158, 2003b.

Browne, F. L.: Theories of the combustion of wood and its control: A literature survey, Forest Products Laboratory, U.S. Department of Agriculture, Report No. 2136, 1-59, 1958.

Christian, T. J., Kleis, B., Yokelson, R. J., Holzinger, R., Crutzen, P. J., Hao, W. M., Saharjo, B. H., and Ward, D. E.: Comprehensive laboratory measurements of biomass burning emissions: 1 . Emissions from Indonesian, African, and other fuels, J. Geophys. Res., 108(D23), 4719, doi:10.1029/JD003704, 2003.

Christian, T. J., Kleis, B., Yokelson, R. J., Holzinger, R., Crutzen, P. J., Hao, W. M., Shirai, T, and Blake, D. R.:
Comprehensive laboratory measurements of biomass-burning emissions: 2 First intercomparison of open-path FTIR, PTRMS and GC-MS/FID/ECD, J. Geophys. Res., 109, D02311, doi:1029/2003JD003874, 2004.

Crutzen, P. J. and Andreae, M. O.: Biomass burning in the tropics: Impact on atmospheric chemistry and biogeochemical cycles, Science, 250, 1669-1678, 1990.

Dimitrakopoulos, A. P.: Thermographic analysis of Mediterranean plant species, J. Anal. and Appl. Pyrolysis, 60, 123-130, 2000.

Fall, R.: Biogenic emissions of volatile organic compounds from higher plants, in: Reactive Hydrocarbons in the Atmosphere, edited by: Hewitt, C. N., Academic Press, London, 41-96, 1999.

Friedli, H. R., Atlas, E., Stroud, V. R., Giovanni, L., Campos, T., and Radke, L. F.: Volatile organic trace gases emitted from North American wildfires, J. Geophys. Res., 15(2), 435-452, 2001.

Geron, C. D., Guenther, A. B., and Pierce, T. E.: An improved model for estimating emissions of volatile organic compounds from forests in the eastern United States, J. Geophys. Res., 99(D6), 12 773-12 791, 1994.

Guenther, A., Hewitt, C. N., Erickson, D., Fall, R., Geron, C., Graedel, T., Harley, P., Klinger, L., Lerdau, M., McKay, W. A., Pierce, T., Scholes, B., Steinbrecher, R., Tallamraju, R., Taylor, J., and Zimmerman, P.: A global model of natural volatile organic carbon emissions, J. Geophys. Res., 100(D5), 8873-8892, doi:10.1029/94JD02950, 1995.

Greenberg, J. P., Zimmerman, P. R., Heidt, L., Lueb, R., and Pollock, W.: Hydrocarbon and carbon monoxide emissions from biomass burning in Brazil, J. Geophys. Res., 89(D1), 1350-1354, 1984.

Greenberg, J. P., Guenther, A., Zimmerman, P., Baugh, W., Geron, C., and Davis, K.: Tethered Balloon measurements of biogenic VOCs in the atmospheric boundary layer, Atmos. Environ., 33, 855-867, 1999.

Greenberg, J. P., Guenther, A. B., Madronich, S., Baugh, W., Ginoux, P., Druilhet, A., Delmas, R., and Delon, C.: Biogenic VOC emissions and chemistry along the EXPRESSO transect in central Africa, J. Geophys. Res., 104(D23), 30 659-30 671, 1999.

Hanson, D., Greenberg, J. P., Henry, B., and Kosciuch, E.: Proton transfer reaction mass spectroscopy at high drift tube pressure, Int. J. Mass Spec., 12 266, 1-12, 2002.

Handbook of Chemistry and Physics, 85 th edition, edited by: Lide, D. R., CRC Press, Cleveland, 2004.

Lacaux, J.-P., Brocard, D., Lacaux, C., Delmas, R., Brou, A., Yoboue, V., and Koffi, M.: Traditional charcoal making: an important source of atmospheric pollution in the African tropics, Atmos. Res., 35, 71-76, 1994.

Liousse, C., Andreae, M. O., Artaxo, P., Barbosa, P., Cachier, H., Gregoire, J. M., Hobbs, P., Lavoue, D., Mouillot, F., Penner, J., Scholes, M., and Schultz, M. G.: Deriving global quantitative estimates for spatial and temporal distributions of biomass burning emissions, in: Emissions of Atmospheric Trace Compounds, edited by: Granier, C., Artaxo, P., and Reeves, C. E.: Advances in Global Change Research, Kluwer Academic Publishers, Dordrecht, 71-113, 2004.

Lobert, J. M., Scharffe, D. H., Hao, W. M., Kuhlbusch, T. A., Seuwen, R., Warneck, P., and Crutzen, P. J.: Experimental evaluation of biomass burning emissions: nitrogen and carbon containing compounds, in: Global Biomass Burning: Atmospheric, Climatic and Biospheric Implications, edited by: Levine, J. S., 
289-304, MIT Press, Cambridge, Mass, 1991.

Pennise, D. M., Smith, K. R., Kithinji, J. P., Rezende, M. E., Raad, T. J., Zhang, J., and Fan, C.: Emissions of greenhouse gases and other airborne pollutants from charcoal making in Kenya and Brazil, J. Geophys. Res., 106(D20), 24 143-24 155, 2001.

Spanel, P. and Smith, D.: Selected ion flow tube studies of the reactions of $\mathrm{H}_{3} \mathrm{O}^{+}, \mathrm{NO}^{+}$, and $\mathrm{O}_{2}^{+}$with several aromatic and aliphatic hydrocarbons, Int. J. Mass Spectrom. Ion Proc., 181, 1-10, 1998.

Taylor, S. W., Wotton, B. M., Alexander, M. E., and Dalrymple, G. N.: Variation in wind and crown fire behavior in a northern jack-pine-black spruce forest, Can. J. For. Res., 34, 1561-1576, 2004.

Wotawa, G. and Trainer, M.: The influence of Canadian forest fires on pollution concentrations in the United States, Science, 288, 324-328, 2000.
Warneke, C., De Gouw, J. A., Kuster, W. C., Goldan, P. D., and Fall, R.: Vaildation of atmospheric VOC measurements by protontransfer-reacton mass spectroscopy using a gas-chromatographic pre-separation method, Environ. Sci. Tech., 37(11), 2494-2501, doi:10.1021/es026266i, 2003.

Yarie, J. and Mead, B. R.: Twig and foliar biomass estimation evaluation for major plant species in the Tanana River Basin of interior Alaska, Research paper \#PNW-RP-401, Pacific Northwest Research Station, U.S. Forest Service, 1988.

Yokelson, R. J., Griffith, D. W. T., and Ward, D. E.: Open path Fourier transform infrared studies of large scale laboratory biomass fires, J. Geophys. Res., 101(D15), 21 067-21 080, 1996.

Yokelson, R. J., Susott, R., Ward, D. E., Reardon, J., and Griffith, D. W. T.: Emissions from smoldering combustion of biomass measured by open-path Fourier transform infrared spectroscopy, J. Geophys. Res., 102(D15), 18 865-18 877, 1997. 